\title{
IMPACT OF TECHNICAL, ORGANIZATIONAL AND HUMAN FACTORS ON ACCIDENT RATE OF SMALL-SIZED ENTERPRISES
}

\author{
Marta NICIEJEWSKA, Adam IDZIKOWSKI \\ Czestochowa University of Technology \\ Katarína LESTYÁNSZKA ŠKURKOVÁ \\ Slovak University of Technology in Bratislava
}

\begin{abstract}
:
The paper focuses on the analysis of the impact of technical, organizational and human factors on accident rate in small-sized enterprises. The research was carried out using the authors' questionnaire. The results were verified using the method of direct interview with elements of observation. The results were compared with the trends prevailing in enterprises of EU countries. The respondents, i.e. production company workers, indicate technical factors as those which most significantly affect the occurrence of accidents at work. However, the assessment of the factors changes with the age of the respondents. Older workers, more often than younger employees, indicate the ones related to man or work organization as the most important factors affecting accidents at work and, consequently, the level of occupational safety. The presented results are a part of a larger whole project the authors of this paper are working on.
\end{abstract}

Key words: occupational health and safety, occupational hazards, small-sized enterprises, technical and organizational factors, human factor, accidents at work

\section{INTRODUCTION}

Small-sized enterprises, i.e.; micro- and small ones, are the core of the many national economies (also in Poland). The small-sized enterprises are considered as the key element among all economic entities, mostly driving economic growth through shaping strongly GDP, but also employment growth and social inclusion [1]. Most workers are employed in small-sized enterprises [2]. Effective [3] management of occupational safety in micro- and small-sized enterprises is therefore essential since providing appropriate and safe working conditions to employees of small-sized enterprises is very important as well as long-term survival in the market. Unfortunately, the results of the publicly available reports in Poland indicate a low level of occupational health and safety in small-sized enterprises [4, 5, 6, 7]. Management of occupational safety in the smallest Polish economic entities is still a challenge both to employers and employees themselves.

\section{LITERATURE REVIEW}

The conditions of the working environment also have a number of deficiencies. Care for safe working conditions in these entities is rare and ergonomics of workstations is a desirable component of optimal working conditions.
Among both employers and employees of small-sized enterprises, there is a lingering conviction that expenditure on occupational safety is only costs. They do not see any benefits in them. Obviously, there are employees who know that expenditure on improvements in working conditions in their companies is a value in itself, the benefit that translates into satisfied, healthy and productive workers. However, there are barriers which do not allow many employers and employees of small-sized enterprises to think in this way $[5,8,9,10,11,12]$. These are mostly high costs of maintaining the company in the market, the magnitude of work done to attract customers, to maintain them and to be competitive in a very dynamic and volatile environment $[13,14,15]$. The average employer does not consider occupational safety in the first place but about a range of barriers which prevent the smooth and effective functioning of their company in the market. There is a tremendous need for change, both in terms of organizational and legal issues but also in terms of employers' awareness regarding the need to create safe and accident-free jobs. Management of occupational safety in small-sized enterprises is not only essential but possible, although it definitely poses a great challenge to employers and employees themselves. 
More than half of the reasons for accidents at work in Poland, for a number of years, has been inappropriate behavior of employees $(60.5 \%)$ predominated by [16]:

- insufficient concentration of attention on the activity performed (25.9\%),

- surprise by an unexpected event (22.8\%),

- ignorance of the risk and inadequate pace of work and lack of experience (6.5\%).

Another important reason for accidents is inappropriate overall organization of work and workstations (9.6\%) [17] The causes of accidents unrelated to human factor, i.e., inadequate condition of the material factor, occur much less frequently $-8.4 \%$ [18]. The elimination of this cause is difficult since it mainly relates to faults in design and ergonomic of the material factor (49.3\%), incorrect operation of the material factor (24.4\%) and material defects (19.9\%), including mostly hidden defects (12.7\%) [16]. Enterprises undertake many preventive measures minimizing the number of accidents at work as well as activities within the framework of "good practices" which may be an inspiration for other enterprises [19, 20, 21, 22].

It can be noted that for several years that the number of accidents at work has been decreasing. The data by the Central Statistical Office indicate that the year of 2019 is another year in which the number of accidents at work decreased. In 2019 a total of 83205 injured persons were reported, i.e., by $1.3 \%$ less than in 2018 . Importantly, the number of fatal accidents has decreased significantly, 184 cases were reported in 2019 , thus by over $11 \%$ less than a year before. Other data to be highlighted are a steady decline in the so-called accident rate since 2014 (the number of the injured per 1000 employees) for the entire economy which amounted to 6.15 last year, compared with 6.37 a year before. According to the analysis by the Central Statistical Office, accident rate, i.e., the number of the injured per 1000 employees amounted to 1.77 for the first half of the year. The value of the rate significantly decreased in relation to the first six months of 2019 when it was 2.54. At the same time, a smaller number of accidents and the injured also translated into lower statistics concerning the types of accidents. By $14.2 \%$ fewer people were injured in serious accidents and by $30 \%$ fewer - as a result of accidents with other consequences [17].

One may wonder if the smaller number of events was the result of the impact of the COVID-19 pandemic and lockdown in the initial months of 2020. The fact is that exactly in the first half of the year, the slowdown in all parts of the economy was visible. In addition, employers are trying to introduce changes in the management of the enterprise (they change the operational strategy) [23], e.g. they have significantly reduced their teams in order not to expose the staff to possible infection, this may be one of the reasons why the accident rate has decreased [24]. There were the most accidents in the industrial processing. In total, 7938 accidents were reported. Importantly, this number decreased by 3373 compared with the corresponding period in 2019. However, a detailed analysis of the nature of the data indicates that, despite the decline in the number of in- cidents across the sector, unfortunately, the number of fatal accidents increased (9 accidents in 2019, 10 in 2020). On the other hand, the number of serious accidents significantly went down (81 incidents in 2019, 62 in 2020) [16]. The sector related to trade in motor vehicles (wholesale and retail) had the second largest share of accidents. There was also a decline in the number of accidents. Only in the first half of 2020 there were 3230 incidents two of which ended with the employee's death, 13 were serious. Transport and warehouse management, in which there were 2042 accidents, including 2 fatal ones and 13 serious ones, came third $[16,25]$.

It also turns out that, compared with the corresponding period of the previous year, the causes of accidents at work did not change, $61 \%$ of them was due to inappropriate behavior of the employee. The other most frequent reasons were inadequate condition of the material factor, inappropriate behavior of the employee and improper operation of the material factor [16]. It is worth pinpointing that one of the causes is also inadequate organization of work and workstation and lack of protective equipment. The reports still indicate that the most important reason for accidents at work is human factor [26]. One may be tempted to say that man is the most unreliable link in the entire work process. What is the reason for that? In the light of the subject literature, the preparation of the employee for safe and accident-free work is first of all determined by initial and instructional training which they must complete to be able to perform employee tasks. These, in turn, in the opinion of employees, are tedious, too long and not adapted to issues of the given industry. The level of the aforementioned training is usually higher in larger entities. In small ones, it constitutes an area where there is still much to be done. This paper is an attempt to pay attention to the fact that, in the smallest economic entities, the broadly understood issue of occupational health and safety is still treated with a grain of salt. The awareness of safe behavior or accidentfree work is the topic to be discussed loudly since there is a great need to raise awareness of safe and accident-free work among the smallest economic operators. Success could be seen in employers but still, in most small-sized enterprises, they are oriented only to profit and maintaining competitiveness. Nowadays, the image of the modern company is not only about creating safe conditions in order to preserve health and life. It is also about creating optimal conditions from the point of view of the needs, capabilities but psychophysical limitations of people working there. Enterprises ought to improve management of occupational health and safety both for the sake of their employees and economic results as well as their market position. Efficient management of occupational health and safety helps not only to comply with the requirements of the applicable law, but also:

- ensures relevant protection of the safety and health of employees,

- has an impact on the reduction in losses related to accidents at work, work-related diseases and inappropriate 
working conditions and also on an increase in the quality and efficiency of work and a positive image of the company,

- supports learning and innovativeness,

- ensures proper and responsible risk management associated with the threats existing in the company,

- makes it easier for employees to understand threats and the need to use appropriate protection measures.

All of these actions constituting the autotelic value, which undoubtedly occupational safety is, ought to be provided by the employer, the owner, the person who is responsible for their employees. Employers forget that, to a very large extent, they are mentors, masters to their subordinates in the company. A very effective operation is the occupational safety management method based on behavior, i.e. Behavioral-Based Safety (BBS). It can be used both in large and the smallest economic units. In the BBS approach, it is assumed that affecting human behavior is more effective than attempts to change behavior through motivation and introduction of measures aimed at the change in the attitude towards occupational safety since, as a consequence, the change in behavior leads to the change in the way of thinking and attitude $[27,28]$. In other words, as a result of the application of behavioral methods over a longer period of time, safe attitude is formed with employees which translates into further safe behavior in the future. Most small-sized enterprises definitely lack such a process.

\section{METHODOLOGY OF RESEARCH}

The presented research results refer to the research carried out before the pandemic period. The questionnaire was sent to enterprises by e-mail. The research using the authors' questionnaire was dedicated to small-sized enterprises, i.e., economic operators with up to 49 employees. 1600 enterprises took part in the survey and it had nationwide coverage. After verification of the collected questionnaires, 1006 of those complete were selected for the analysis. In terms of the age structure, the most numerous group of respondents was employees aged 35-44-37.9\%. More than half of those questioned worked for longer than 6-10 years. Nearly $3 / 4$ of the employees declared that they performed a professional job of a physical or mixed nature (mental and physical). More than $60 \%$ of those questioned declared that they had secondary or higher education. In order to verify the research results, direct interviews were conducted with elements of observation in selected production companies of the Silesian Voivodeship. The Voivodeship selected for additional research was chosen on the basis of the following premises:

- the industry which most often responded to the question was production companies,

- the most complete questionnaires were obtained from the Silesian Voivodeship,

- availability and consent to direct penetration of the company (consent to discussions and observation of employees during work).

\section{RESULTS OF RESEARCH}

The objective of this paper was to assess the impact of technical, organizational and human factors on accidents at work, in the opinion of employees of small-sized enterprises and, consequently, the level of occupational safety. On the basis of the results, the analysis of the aforementioned factors was conducted in order to establish which of them have the largest impact on the occurrence of accidence at work. Table 1 contains the results concerning the distribution of the indicated reasons for accidents at work, occurring the most often in the opinion of the respondents, broken down by the sector of activity.

Table 1

Distribution of indications (by means) of the reasons for accidents at work occurring the most often in the opinion of the respondents broken by the sector activity and the results of the significance difference test between the indications for the production and service sectors

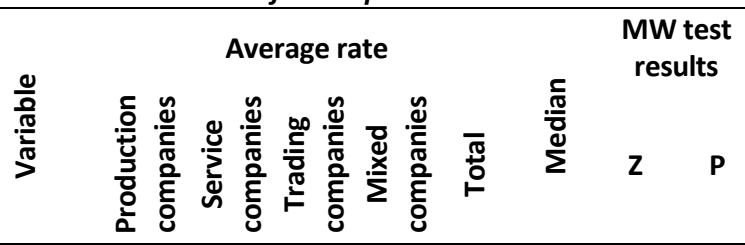
Technical
factors
Organiza-
tional $\quad 3.9793 .8033 .5563 .7073 .8234 .0002 .8830 .004$
factors
Human
factor 4.3073 .8063 .6673 .9543 .9544 .0007 .3230 .000
Own study * - statistically significant values at $\alpha=0.05$

More than half of the respondents acknowledged that each of the listed reasons for accidents is very important. In general terms, technical occupational safety was rated the highest (3.999), in production companies, human factor was rated higher (4.307) as the cause of threats, significantly higher than in the service sector $(Z=7.232$, $\mathrm{p}<0.001)$. In terms of the differences, the production sector also assessed the possibility of causing an accident due to (inappropriate) work organization higher than the service sector $(Z=2.883, p=0.004)$.

In turn, Table 2 contains the results concerning the distribution of the indications of the reasons for accidents at work occurring the most often in the opinion of the respondents, broken down by their age.

Table 2

Distribution of indications (by means) of the reasons for accidents at work occurring the most often in the opinion of the respondents, broken down by their age and the value of Kendall's tau coefficient between age and reasons for accidents Age Correlation

\begin{tabular}{|c|c|c|c|c|c|c|c|c|c|}
\hline Variables & $\begin{array}{l}18- \\
24 \\
\end{array}$ & $\begin{array}{l}25- \\
34 \\
\end{array}$ & $\begin{array}{l}35- \\
44 \\
\end{array}$ & $\begin{array}{l}45- \\
54 \\
\end{array}$ & $\begin{array}{l}56- \\
64 \\
\end{array}$ & $\begin{array}{c}65 \text { and } \\
\text { over }\end{array}$ & Total & Tau & $P$ \\
\hline $\begin{array}{l}\text { Technical } \\
\text { factors }\end{array}$ & $\begin{array}{l}\infty \\
\stackrel{\infty}{\rho} \\
\dot{m}\end{array}$ & $\hat{\widehat{\sigma}}$ & $\stackrel{\stackrel{n}{n}}{\stackrel{n}{n}}$ & 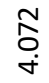 & $\begin{array}{l}\text { O } \\
\text { ஸे } \\
\text { n் }\end{array}$ & $\begin{array}{l}\text { 员 } \\
\text { i }\end{array}$ & ஜ & 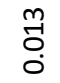 & \& \\
\hline $\begin{array}{l}\text { Organizational } \\
\text { factors }\end{array}$ & 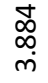 & 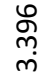 & $\underset{n}{\stackrel{\infty}{b}}$ & $\underset{\substack{n \\
\sigma \\
n}}{n}$ & 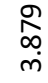 & $\begin{array}{l}\stackrel{\circ}{\stackrel{h}{n}} \\
\text { m }\end{array}$ & $\begin{array}{l}\tilde{N} \\
\infty \\
m \\
m\end{array}$ & f & సે \\
\hline Humar & $\begin{array}{l}\operatorname{Ln}_{0}^{n} \\
\infty \\
\dot{m}\end{array}$ & $\underset{\substack{n \\
m}}{m}$ & $\begin{array}{l}\stackrel{n}{\infty} \\
\infty \\
\dot{m}\end{array}$ & 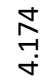 & 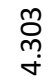 & 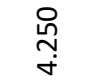 & 亗 & $\begin{array}{l}\stackrel{0}{n} \\
\stackrel{\circ}{0}\end{array}$ & 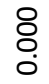 \\
\hline
\end{tabular}

Own study * - statistically significant values at $\alpha=0.05$ 
The older the employees the more often they indicate the importance of work organization $(r \tau=0.047, p=0.027)$ and human factor ( $r \tau=0.136, p<0.001)$ as the reasons for accidents at work. These relationships ought to be defined as weak.

Table 3 contains the results concerning the difference in ratings of the reasons for accidents from the point of view of employees of micro- and small-sized enterprises.

Table 3

The difference in assessments of the reasons for accidents from the point of view of employees of micro- and small enterprises (The Mann-Whitney $U$ Test results)

\begin{tabular}{cccccc}
\hline Variable & \multicolumn{2}{c}{ Micro- } & \multicolumn{2}{c}{ Small } & \multicolumn{2}{c}{ MW Test results } \\
& enterprises & \multicolumn{2}{c}{ enterprises } & MW \\
mean & SD & mean & SD & $\mathbf{Z}$ & $\mathbf{P}$ \\
\hline
\end{tabular}

\begin{tabular}{|c|c|}
\hline $\begin{array}{l}\text { Technical } \\
\text { factors }\end{array}$ & $3.96190 .74794 .04400 .8375-2.4297 * 0.0151$ \\
\hline $\begin{array}{c}\text { Organizational } \\
\text { factors }\end{array}$ & $3.76410 .77083 .89450 .9053-3.1288 * 0.0018$ \\
\hline
\end{tabular}

Human factor $4.04720 .82033 .84180 .97512 .9636 * 0.0030$

Own study * - statistically significant values at $\alpha=0.05$

Employees of small-sized enterprises indicate the reasons for accidents due to technical occupational safety $(Z=-2.4297 ; p=0.0151)$ and work organization $(Z=-3.1288 ; p=0.0018)$ significantly more often than micro-company workers. In turn, employees of micro-enterprises significantly more often indicate human factor as the reason for accidents $(Z=2.9636 ; p=0.0030)$.

\section{DISCUSSION}

In order to relate to the results from the conducted research using the questionnaire, in selected small-sized enterprises, additional open observation was made with elements of direct interview. The enterprises selected for this research are micro- and small construction companies (45 economic operators). All of the entities are in the area of the Silesian Voivodeship. The construction sector subjected to further analysis belongs to the group of economic entities in which one may observe a large number of accidents at work, in particular fatal ones. These statistics are influenced by the situation in micro- and small construction companies, which take part in the realization of large and small investments, thus constituting the vast majority of enterprises involved in construction sites. The complexity of their functioning in the field of occupational health and safety, among others, resulting from a difficult economic situation, affects the fact that construction belongs to the sections of the economy with one of the highest accident rates.

Construction companies were selected from among those participating in the survey using the questionnaire. The visits were arranged by phone well in advance. The period of observation with elements of direct interview lasted for about a year. The visits were paid before the pandemic. From among 45 economic entities, 32 belonged to microenterprises (up to 9 employees) and 13 - to small-sized enterprises (with 10-49 employees). All the surveyed companies were most frequently employed as subcon- tractors of larger construction investments. They also implemented independent projects, in particular construction and repair ones. Only 5 companies from among 45 subjected to observation with elements of direct interview had the functioning management system. As already mentioned, there is high complexity of the operation of small-sized construction companies in terms of occupational health and safety. Unfortunately, this is confirmed by the observation with elements of direct interview made in the area of 45 small-sized entities.

Observation with elements of direct interview supported by selected questions of the authors' questionnaire concerned many thematic areas related to occupational safety. For the purposes of this paper, the area concerning the threats determining occupational safety in the company was selected, in terms of accidents at work, the reasons for which may be technical, organizational and human factors.

The observations made, supported by elements of direct interview indicate that, in the surveyed small-sized construction companies, the greatest threats are related to human factor. In the observed construction sites, the most frequent irregularities were inappropriate (dangerous) behavior of employees, which, among others, manifested themselves in:

- non-compliance with the rules of manual transport,

- absence of care for ergonomic body positions when handling heavy materials,

- absence of security for work at height.

This dangerous and irresponsible behavior was observed especially in small-sized entities (with 10-49 employees), in which there was a high staff turnover and most of them were a group with less than a year of work experience in the current position. There were many irregularities observed in selected companies. The most extreme ones included:

- cases of insobriety among employees in the construction site ( 2 cases in micro-enterprises),

- throwing scaffolds and tools from heights without observing safety rules (in 12 economic operators $-10 \mathrm{mi}-$ cro-and 2 small ones),

- lack of care for order in the construction site (in $20 \mathrm{mi}$ cro- and 6 small-sized enterprises).

Technical factors were indicated by employees as the second important area having a direct impact on the occurrence of accidents, and thus the level of occupational safety. The identification of threats in terms of technical factors, due to the observation supported by elements of direct interview, allowed for the formulation of the following conclusions:

- employees in the observed entities rarely use personal protective equipment, e.g., anti-vibration gloves, helmets, masks,

- employees do not have information on the analyses of malfunctions and breakdowns of machinery and equipment conducted by the employer,

- employees do not have information on preventive inspections and corrective maintenance of machinery and equipment, 
- in the opinion of employees, the factors causing the most trouble at work are microclimate, i.e. work in different weather conditions, noise in the construction site and the presence of dust during construction works: earthworks, concrete, assembly, finishing or demolition works.

In the opinion of the respondents, organizational factors also have an impact on occupational safety and the occurrence of accidents at work, but to the slightest extent from among those taken into account. The identification of threats in terms of organizational aspects, as a result of the observation supported by elements of direct interview, allowed for the formulation of the following conclusions:

- there is no inventory of hazardous works in enterprises (24 small-sized, 12 micro-enterprises),

- employees do not have information on methods that would limit or eliminate accident hazards (24 smallsized, 13 micro-enterprises),

- there is no care for reducing physical effort and monotony of work in companies (26 small-sized, $11 \mathrm{mi}-$ cro-enterprises),

- employees show no need to maintain order in the construction site (20 small-sized, 9 micro-enterprises).

The identification of threats in terms of human factor, due to the observation supported by elements of direct interview, allowed for the formulation of the following conclusions:

- limits of working time are not respected in the observed construction companies (26 small-sized, $13 \mathrm{mi}-$ cro-enterprises),

- employees complain about the lack of adequate remuneration for overtime worked (6 small-sized, 2 microenterprises),

- employees do not have information on the results of the occupational risk assessment ( 28 small-sized, 4 micro-enterprises),

- employees do not know the methods and measures promoting safe and accident-free work (28 smallsized, 12 micro-enterprises),

- there are no registers of accidents at work in enterprises (16 small-sized, 11 micro-enterprises).

The identification of the occurrence of threats in smallsized construction companies, in the opinion of employees, confirms trends prevailing in these entities in the light of reports by the National Labor Inspectorate. Also, the results of the research conducted by the authors using the questionnaire do not differ from the results of observations with elements of direct interview since it appears that the problems faced by small-sized enterprises in terms of occupational health and safety are very similar and concern very similar issues.

\section{SUMMARY AND CONCLUSION}

The need to create the awareness of employees in terms of safe (accident-free) behavior should be the priority in each organization. Even more since, as indicated by reports or at least the research results presented in this article, human factor is the most significant source of the reasons for accidents at work. It is a great challenge in the smallest economic operators. The employer or the manager has always been the human capital in whom other employees could see the master, someone who will pave the way in the process of work etc. Nowadays, there is also a large need to create the awareness of owners and employers themselves, particularly those of the smallest economic operators which are currently struggling to survive in the market and to be competitive. They very often save on training, which translates into their quality. They also have a very economical attitude towards the purchase of protective equipment. The role of the master, mentor in the thought of the aforementioned principle of Behavioral-Based Safety is necessary in the process of creating the awareness of safe and accident-free work among employees. However, it is a very neglected area, especially in the smallest economic operators.

\section{REFERENCES}

[1] M.J. Piątkowski, "Results of SME Investment Activities: A Comparative Analysis among Enterprises Using and Not Using EU Subsidies in Poland," Administrative Sciences, vol. 10, no. 1, p. 4, 2020, doi: 10.3390/admsci10010004.

[2] P. Chaber, J. Łapiński, M. Nieć, and J. R. Z. Orłowska, Raport o stanie sektora małych i średnich przedsiębiorstw w Polsce. Warszawa: PARP, 2020.

[3] D. Klimecka-Tatar and M. Niciejewska, "Small-sized enterprises management in the aspect of organizational culture," Revista Gestão \& Tecnologia - Journal of Management and Technology, vol. 1, pp. 4-24, 2021, doi: 10.20397/2177-6652/2021.v21i1.2023.

[4] M. Pałęga and M. Knapiński, "Assessment of Employees Level of Awareness in the Aspect of Information Security," System Safety: Human - Technical Facility - Environment, vol. 1, no. 1, pp. 132-140, 2019, doi: 10.2478/czoto-20190017.

[5] M. Niciejewska and D. Klimecka-Tatar, "Health problems among employees in small enterprises as a result of improper OHS management," MATEC Web Conf., vol. 183, p. 1012, 2018, doi: 10.1051/matecconf/201818301012.

[6] M. Ingaldi and R. Ulewicz, "Problems with the Implementation of Industry 4.0 in Enterprises from the SME Sector," Sustainability, vol. 12, no. 1, p. 217, 2020, doi: 10.3390/su12010217.

[7] M. Niciejewska and O. Kiriliuk, "Occupational health and safety management in "small size" enterprises, with particular emphasis on hazards identification," Production Engineering Archives, vol. 26, no. 4, pp. 195-201, 2020, doi: 10.30657/pea.2020.26.34.

[8] K. Teplická and S. Hurná, “New Approach of Costs of Quality According their Trend of During Long Period in Industrial Enterprises in SMEs," Management Systems in Production Engineering, vol. 29, no. 1, pp. 20-26, 2021, doi: 10.2478/mspe-2021-0003.

[9] D. Klimecka-Tatar and O. Matevž, "The Level of Occupational Health and Safety in European Enterprises Providing Transport and Logistics Services in Terms of Quality Management Principles," Multidisciplinary Aspects of Production Engineering, vol. 3, no. 1, pp. 394-404, 2020, doi: 10.2478/mape-2020-0034. 
[10] J. Żywiołek and A. Di Taranto, "Creating Value Added for an Enterprise by Managing Information Security Incidents," System Safety: Human - Technical Facility - Environment, vol. 1, no. 1, pp. 156-162, 2019, doi: 10.2478/czoto-2019-0020.

[11] M. Krynke and K. Mielczarek, "Applications of linear programming to optimize the cost-benefit criterion in production processes," MATEC Web Conf., vol. 183, p. 4004, 2018, doi: 10.1051/matecconf/201818304004.

[12] A. Woźny, "Selected problems of managing work safety case study," Production Engineering Archives, vol. 26, no. 3, pp. 99-103, 2020, doi: 10.30657/pea.2020.26.20.

[13] D. Klimecka-Tatar and M. Ingaldi, "How to indicate the areas for improvement in service process - the Knowledge Management and Value Stream Mapping as the crucial elements of the business approach," G\&T, vol. 20 , no. 2 , pp. 52-74, 2020, doi: 10.20397/2177-6652/2020.v20i2.1878.

[14] M. Krynke, "Risk Management in the Process of Personnel Allocation to Jobs," System Safety: Human - Technical Facility - Environment, vol. 2, no. 1, pp. 82-90, 2020, doi: 10.2478/czoto-2020-0011.

[15] Y. Ma, Q. Zhao, and M. Xi, "Decision-makings in safety investment: An opportunity cost perspective," Safety Science, vol. 83, no. 10, pp. 31-39, 2016, doi: 10.1016/j.ssci.2015.11.008.

[16] Główny Urząd Statystyczny, Wypadki przy pracy. Warszawa, 2020.

[17] J. Lewandowski and M. Niciejewska, Eds., Bezpieczeństwo pracy w polskich przedsiębiorstwach "małej wielkości", ze szczególnym uwzględnieniem profilu produkcyjnego - wybrane aspekty": Inżynieria zarzqdzania. Cyfryzacja produkcji. Aktualności badawcze 1. Warszawa: PWE, 2019.

[18] A. K. Stasiuk-Piekarska and M. K. Wyrwicka, Corporate Social Responsibility in Manufacturing - Good Practices, Advantages and Limitations: Golinska-Dawson P., Spychała $M$. (eds) Corporate Social Responsibility in the Manufacturing and Services Sectors. EcoProduction (Environmental Issues in Logistics and Manufacturing). Berlin, Heidelberg: Springer, 2019. Accessed: https://doi.org/10.1007/978-3642-33851-9_12.

[19] R. Ulewicz, F. Nowy, and R. Dwornicka, "Quality and work safety in metal foundry," Proceedings $29^{\text {th }}$ International Conference on Metallurgy and Materials, Brno, Czech Republic, EU, May 20-22, 2020, pp. 1287-1293, 2020, doi: 10.37904/metal.2020.3649.

\section{Marta Niciejewska}

ORCID ID: 0000-0002-9530-3455

Czestochowa University of Technology

Faculty of Management

ul. Dąbrowskiego 69, 42-201 Częstochowa, Poland

e-mail: marta.niciejewska@wz.pcz.pl

\section{Adam Idzikowski}

ORCID ID: 0000-0003-1178-8721

Czestochowa University of Technology

Faculty of Management

ul. Dąbrowskiego 69, 42-201 Częstochowa, Poland

e-mail: adam.idzikowski@wz.pcz.pl
[20] R. Ulewicz and L. V. Lazar, "The Effect of Lean Tools on the Safety Level in Manufacturing Organisations," System Safety: Human - Technical Facility - Environment, vol. 1, no. 1, pp. 514-521, 2019, doi: 10.2478/czoto-2019-0066.

[21] A. Zyska and O. Kiriliuk, "Influence of Life Style on Safety and Work Efficiency," System Safety: Human - Technical Facility - Environment, vol. 2, no. 1, pp. 62-72, 2020, doi: 10.2478/czoto-2020-0009.

[22] K. Wojtasik, "New Impulse, New Challenges. Safety Procedures in a Production Enterprise. A Case Study," System Safety: Human - Technical Facility - Environment, vol. 2, no. 1, pp. 26-32, 2020, doi: 10.2478/czoto-2020-0004.

[23] N. Baryshnikova, O. Kiriliuk, and D. Klimecka-Tatar, "Enterprises' strategies transformation in the real sector of the economy in the context of the COVID-19 pandemic," Production Engineering Archives, vol. 27, no. 1, pp. 8-15, 2021, doi: 10.30657/pea.2021.27.2.

[24] J. Michie, "The covid-19 crisis - and the future of the economy and economics," International Review of Applied Economics, vol. 34, no. 3, pp. 301-303, 2020, doi: 10.1080/02692171.2020.1756040.

[25] V. P. Anderson, P. A. Schulte, J. Sestito, H. Linn, and L. S. Nguyen, "Occupational fatalities, injuries, illnesses, and related economic loss in the wholesale and retail trade sector," American journal of industrial medicine, vol. 53, no. 7, pp. 673-685, 2010, doi: 10.1002/ajim.20813.

[26] J. Grabara, M. Dabylova, and G. Alibekova, "Impact of legal standards on logistics management in the context of sustainable development," $A L$, vol. 7, no. 1, pp. 31-37, 2020, doi: 10.22306/al.v7i1.155.

[27] B. Skowron-Grabowska and M. D. Sobociński, "Behaviour Based Safety (BBS) - Advantages and Criticism," Production Engineering Archives, vol. 20, no. 20, pp. 12-15, 2018, doi: 10.30657/pea.2018.20.03.

[28] M. Niciejewska and M. Obrecht, "Impact of Behavioral Safety (Behavioural-Based Safety - BBS) on the Modification of Dangerous Behaviors in Enterprises," System Safety: Human - Technical Facility - Environment, vol. 2, no. 1, pp. 324-332, 2020, doi: 10.2478/czoto-2020-0040.

\author{
Katarína Lestyánszka Škurková \\ ORCID ID: 0000-0003-0088-5454 \\ Slovak University of Technology in Bratislava \\ Faculty of Materials Science and Technology in Trnava \\ Trnava, Slovakia \\ e-mail: katarina.skurkova@stuba.sk
}

